\title{
INTERNATIONAL LAW, DOMESTIC LENSES
}

\author{
Marco Benatar ${ }^{*}$
}

\begin{abstract}
This article makes the case for greater attention to be given to the role of national legal culture in the making and practice of international law. The merits of this contested notion as a tool for gaining new insights are discussed, as is the legal cultural approach embedded in the broader field of study known as "comparative international law". In an effort to demonstrate the utility of engaging with this concept, the focus turns to the inner legal culture of international law, which is composed of lawyers, judges and other professionals. It is argued that there are two factors of influence which allow for domestic elements to seep into international law. The first relates to individuals, via the inculcation of parochial values, whereas the second takes on a structural dimension, through inter alia the general principles of law and the "equitable geographical representation" requirement found in the statutes of many intergovernmental bodies. This theoretical framework is subsequently applied to the International Court of Justice, a suitable case study on account of it being a meeting place of various juridical traditions. At the individual level, judges and counsel appearing before the ICJ are considered. As regards the structural level, certain institutional features conducive to domestic influences are highlighted. Finally, the article identifies and briefly discusses three themes in the jurisprudence of the ICJ where national legal cultures have left their mark: analogies to municipal law, the manner and style in which the outcome of cases are justified and the debates surrounding the standard of proof.
\end{abstract}

\section{Introduction}

Public international law is traditionally viewed as a single corpus of positive law binding upon all states and other entities bestowed with international legal personality. ${ }^{1}$ Despite this tenet of universality, a trait common among all legal

\footnotetext{
Ph.D. Fellow, Research Foundation-Flanders (FWO); Member, Centre for International Law, Free University of Brussels (Vrije Universiteit Brussel), Belgium. The author would like to thank Olivier Barasalou, Sanjivi 'Deen' Krishnan and Tamás Hoffmann for their comments and support.

1 B Simma, 'Universality of International Law from the Perspective of a Practitioner' (2009) 20 EJIL 265, 267. See also S Dellavalle, 'Beyond Particularism: Remarks on Some Recent Approaches to the Idea of a Universal Political and Legal Order' (2010) 21 EJIL 765.
}

Copyright $\odot$ the Author(s).

This work is licensed under a Creative Commons Attribution-NonCommercial-NoDerivs 3.0 License. 
systems, ${ }^{2}$ international legal practitioners often disagree with their counterparts hailing from other jurisdictions on the interpretation and content of norms, the best legal solutions to global problems, and other challenges. Where does the source of these discrepancies lie? Legal and political science scholars have gone to great lengths to provide explanations for this phenomenon, ranging from military strength to domestic political structures and regional integration. As compelling as certain of these accounts may be, there is another potential factor that has received less attention in academia: national legal culture. Lawyers, steeped as they are in a given domestic tradition of law, ${ }^{3}$ carry an intellectual background and a set of internalized values that they export to the international plane. When engaging with problems pertaining to international law, the desire to think in terms and concepts analogous with their municipal legal systems can be strong. This paper aims to set the stage for a discussion on the role of this hitherto fairly neglected criterion in construing and expounding the building blocks of the global juridical order. I will discuss the notion of legal culture, and offer some methodological thoughts on how it could serve as a useful angle via which to perceive the international legal framework. Thereafter, I will briefly consider certain aspects of the International Court of Justice (ICJ) in an attempt to show how the legal culture approach can yield interesting insights.

\section{A legal cultural approach to international law}

\subsection{A contested notion}

\subsubsection{Advantages}

Using legal culture as a lens through which to observe legal phenomena has a sound premise: the focus of analysis should not be restricted to law in the books. Advocates of this research tool argue they are better equipped to scratch beneath the surface so as to reveal the deeper reality. Being at the meeting point of comparative legal studies and legal sociology, the cultural method shows promise in both disciplines. Among comparativists, it is maintained that the cultural paradigm has a decisive advantage over positivists, who neglect non-rule

\footnotetext{
2 P Bourdieu, 'The Force of Law: Toward a Sociology of the Juridical Field' (1987) 38 Hastings LJ $814,843-4$.

3 W E Butler, 'International Law and the Comparative Method', in W E Butler (ed), International Law in Comparative Perspective (1980) 25, 33.
} 
elements that influence the workings of law in practice. ${ }^{4}$ By understanding and embracing differences, they also offer a fresh alternative to functionalists who are in the habit of distilling similarities with a view to promoting the conventional aims of comparative law, such as legislative reform. ${ }^{5}$ With respect to socio-legal studies, the cultural paradigm can present novel explanations for the rationale behind the legal system when a logical link is lacking between certain aspects of the law (rules, structures, institutions etc.) and the society in which it operates. ${ }^{6}$

\subsubsection{Definition}

Legal culture thus presents itself as an attractive method, but what does it precisely mean? Defining this concept is a difficult, elusive task. A variety of experts working within the disciplines that gave rise to this term of art are at loggerheads. A suitable starting point is the work of Friedman, credited by many as having introduced this concept into American socio-legal parlance. In his opinion, legal culture is 'what people think about law, lawyers and the legal order, it means ideas, attitudes, opinions and expectation with regard to the legal system.' This can be contrasted with Nelken's broader understanding of the notion, which also includes values and ideas but adds to the mix many forms of behavior deemed legally relevant. ${ }^{8}$ Offering a quite different conceptualisation, Blankenburg distinguishes between the supply ((para)legal institutions) and demand (uses of the aforementioned institutions) side of law in his analysis of legal culture. ${ }^{9}$ Hence, a brief overview of the pertinent literature suffices to conclude that definitions are legion. Despite the discrepancies, as the lowest common denominator, legal culture could be described as a conceptual framework used by the more sociologically inclined to conduct meaningful research into legal phenomena and their setting in the broader society.

${ }^{4}$ R Cotterrell, 'Comparative Law and Legal Culture', in M Reimann \& R Zimmermann (eds), The Oxford Handbook of Comparative Law (2006) 709, 710-11.

${ }^{5}$ H P Glenn, 'Aims of Comparative Law', in J M Smits (ed), Elgar Encyclopedia of Comparative Law (2006) $57,60-2$.

${ }^{6}$ A Watson, 'Legal Culture $v$ Legal Tradition', in M Van Hoecke (ed), Epistemology and Methodology of Comparative Law (2004) 1, 4.

7 L M Friedman, 'The Place of Legal Culture in the Sociology of Law', in M Freeman (ed), Law and Sociology: Current Legal Issues (2006) 185.

8 D Nelken, 'Using the Concept of Legal Culture' (2004) 29 Australian J Leg Phil 1, 1.

9 E Blankenburg, 'Civil Litigation Rates as Indicators for Legal Culture', in D Nelken (ed), Comparing Legal Cultures (1997), 41. 


\subsubsection{Criticisms}

A contested notion to say the least, the cultural paradigm is not without its critics. Roughly speaking, detractors can be placed into two categories. The milder bunch acknowledges the merit of this approach, yet disagrees on the specifics. ${ }^{10}$ Attempts to develop new paradigms for grasping legal culture will inevitably bring about internal quibbles and turf wars. A more fundamental critique however questions the very utility of referring to legal culture. ${ }^{11}$ One of the major points of contention is the manner in which 'culture' has been used as an epistemological tool in the social sciences. ${ }^{12}$ Not only is the term often described in a vague, over-inclusive style diminishing its analytic usefulness, it can lead to more harmful unintended consequences: viewing one's own culture as a homogenous unit without any inconsistencies and incommensurable with other cultures, thus leading to unavoidable conflict wherever they meet. ${ }^{13}$ Furthermore, although equally engaged in the enterprise of unearthing the correlation between law and society, some scholars prefer seeking recourse to germane concepts and jargon. Examples thereof are 'legal ideology', which refers to assumptions and values as manifested through legal doctrine, ${ }^{14}$ and 'legal mentalité, which connotes a type of mindset shared by a given community. ${ }^{15}$

\subsection{Applying the paradigm}

\subsubsection{An exercise in comparative international law}

Before operationalizing the paradigm at the international level, some thought should be given to the place it occupies among the manifold methodologies of international law. It is apparent that taking as our underlying premise the view that legal culture (i.e. a social factor outside of the positive rules) ${ }^{16}$ affects behavior will inexorably lead us into the realm of sociology of international law. ${ }^{17}$ But,

${ }^{10}$ D Nelken, 'Legal Culture', in J M Smits (ed), Elgar Encyclopedia of Comparative Law (2006) 372, 373-374.

${ }^{11}$ D Nelken, 'Comparing Legal Cultures', in A Sarat (ed), The Blackwell Companion to Law and Society (2004) 113, 116.

12 A Acar, 'The Concept of Legal Culture' (2006) 3 Ankara LR 143, 147.

${ }^{13}$ H P Glenn, 'Legal Cultures and Legal Traditions', in Van Hoecke, above n 6, 7, 15-17. See also W Twining, General Jurisprudence: Understanding Law from a Global Perspective (2009) 80-1.

${ }^{14}$ R Cotterrell, The Sociology of Law: An Introduction (2 ${ }^{\text {nd }}$ edn, 1992) 115.

15 P Legrand, 'European Legal Systems are not Converging' (1996) 45 ICLQ 52, 60-64.

${ }^{16}$ O Corten, Méthodologie du droit international public (2009) 33.

${ }^{17}$ M Hirsch, 'The Sociology of International Law: Invitation to Study International Rules in their Social Context' (2005) 55 U Toronto LJ 891, 893. 
more notably, the advocated paradigm can be seen as an attempt to bolster the study of a fairly unfamiliar approach: 'comparative international law' $(C I L) .{ }^{18}$ The CIL project includes inter alia discerning national, ${ }^{19}$ regional, ${ }^{20}$ and common law vs. civil law ${ }^{21}$ approaches to international law, comparing the foreign relations law of countries, and exploring alternative narratives to the classical, Eurocentric understandings of the international legal order originating in other parts of the world. $^{22}$

CIL has received scant attention in the literature. ${ }^{23}$ Take for instance the 1998 symposium hosted by the American Journal of International Law on the methods of international law. Showcasing a variety of approaches ranging from classical positivism to interdisciplinary IR/IL, the end result was an impressive prospectus of international legal approaches.

Conversely, the comparative method failed to make the cut, receiving brief acknowledgment and relegated to a single footnote reference. ${ }^{24}$ This is, to a certain extent, understandable for a couple of reasons. At first blush, both

${ }^{18}$ On the different meanings that have been given to CIL, see: B N Mamlyuk \& U Mattei, 'Comparative International Law' (2011) 36 Brooklyn JIL 385, 388-9. For a discussion on the various uses of the comparative technique in international law, see: W E Butler, 'Comparative Approaches to International Law' (1985) 190 RCADI 9. An alternative understanding of CIL can be found in A Roberts, 'Comparative International Law? The Role of National Courts in Creating and Enforcing International Law' (2011) 60 ICLQ 57, 57 (the phenomenon of '[a]cademics, practitioners and international and national courts [...] increasingly seeking to identify and interpret international law by engaging in comparative analyses of various domestic court decisions.').

${ }^{19}$ E.g. L Delabie, Approches américaines du droit international: entre unité et diversité (2011); 'Symposium on French and American Perspectives towards International Law and International Institutions' (2006) 58 Maine LR 28; 'Diverging Anglo-American Attitudes to International Law' (1972) 2 Georgia JICL 1.

${ }^{20}$ E.g. 'Europe and International Law' (2004) 15 EJIL 857; H Ruiz Fabri, 'Reflections on the Necessity of Regional Approaches to International Law through the Prism of the European Example: Neither Yes nor No, Neither Black nor White' (2010) 1 Asian JIL 1.

${ }^{21}$ E.g. C H Koch, Jr, 'Envisioning a Global Legal Culture' (2003) 25 Mich JIL 1. Cf H Lauterpacht, 'The So-Called Anglo-American and Continental Schools of Thought in International Law' (1931) 12 BYIL 31.

${ }^{22}$ E.g. Leiden JIL's Periphery Series; A Becker Lorca, 'Universal International Law: NineteenthCentury Histories of Imposition and Appropriation' (2010) 51 Harv ILJ 475.

${ }^{23}$ For a critique of the CIL project, see: I Brownlie, 'Remarks: Comparative Approaches to the Theory of International Law' (1986) 80 ASIL Proc 154.

${ }^{24}$ S R Ratner \& A M Slaughter (eds), The Methods of International Law (2004) 4 (n 13). See similarly R Cryer, T Hervey, B Sokhi-Bulley \& A Bohm, Research Methodologies in EU and International Law (2011) 12, 28-29. 
disciplines seem worlds apart. ${ }^{25}$ The limited role that internationalists accept for the comparative technique is that of bringing to light the general principles of law ${ }^{26}$ and getting a better grasp of concepts and institutions of customary international law, such as pacta sunt servanda, clausula rebus sic stantibus, pacta tertiis, and abus de droit, that find their inspiration in domestic systems. ${ }^{27}$ The law of treaties has generally been considered one of the more fertile areas for comparative research in this regard. ${ }^{28}$ Secondly, in recent years, although several excellent articles have been written on topics that could fall within the remit of CIL, there has not been a distinct school espousing the comparative method in international legal studies. ${ }^{29}$ If current developments are an indication, this might change in the future. After several years of relative silence, two articles with 'comparative international law' in their title were published in 2011 calling for renewed interest in the CIL endeavour. ${ }^{30}$ To this, one can add a number of workshops dedicated to the same theme. ${ }^{31}$

Within this comparative setting, recourse to juridical culture as advocated in the present paper is not entirely new. Mention should be made of several book-length works that have been published utilizing this perspective in one way or another. The French Society for International Law together with the German Society of International Law published the proceedings of a colloquium on this very topic. $^{32}$ Other tomes have focused on national legal culture as an explanation

${ }^{25}$ D Kennedy, 'New Approaches to Comparative Law: Comparativism and International Governance' (1997) 2 Utah LR 545, 633; L A Obiora, 'Toward an Auspicious Reconciliation of International and Comparative Analyses' (1998) 46 AJCL 669, 672.

${ }^{26}$ G A Bermann, 'Le droit comparé et le droit international: alliés ou ennemis? La conférence' (2003) 55 Rev int dr comp 519, 521; L C Green, 'Comparative Law as a "Source" of International Law' (1967) 42 Tulane LR 52.

${ }^{27} \mathrm{~K}$ Zweigert \& H Kötz, An Introduction to Comparative Law ( $3^{\text {rd }}$ edn, 1998) 7-8; A A Cançado Trindade, 'La méthode comparative en droit international, une perspective européenne' (1977) 55 RDISDP 273, 278.

${ }^{28}$ H C Gutteridge, 'Comparative Law and the Law of Nations' (1944) 21 BYIL 1, 8-9; P Reuter, 'La nature des vices du consentement dans la Convention de Vienne sur le droit des traités', in E Van Bogaert, Liber Amicorum Elie Van Bogaert (1985); C J Mahoney, 'Treaties as Contracts: Textualism, Contract Theory, and the Interpretation of Treaties' (2007) 116 Yale LJ 824.

${ }^{29}$ For a historical overview of the development of CIL, see: Mamlyuk \& Mattei, above n 18.

${ }^{30}$ Ibid; M Koskenniemi, 'The Case for Comparative International Law' (2009) 20 Finnish YIL 1.

${ }^{31}$ E.g. Toronto Group for the Study of International, Transnational, and Comparative Law, $3^{\text {rd }}$ Annual Conference, Panel 'Stories of the Gently Civilized: National Traditions in International Law', 29-31 January 2010, <http://torontogroup.files.wordpress.com/2009/08/toronto-group2010-call-for-papers.pdf $>$ [accessed 1 May 2013].

${ }^{32}$ Société française pour le droit international (ed), Droit international et diversité des cultures juridiques/International Law and Diversity of Legal Cultures (2008). See also Société française 
for reservations to and the interpretation of human rights treaties, ${ }^{33}$ differing perspectives on the use of force, ${ }^{34}$ its importance in the jurisprudence of the WTO's Appellate Body, ${ }^{35}$ and how it relates to international courts. ${ }^{36}$

\subsubsection{National legal cultures \& the internal world of international law}

The goal of this paper is to foster dialogue on the ways to assess the influence that national legal background, traditions, perceptions etc. exert with respect to the international system. ${ }^{37}$ The unit of comparison is situated at the meso-level somewhere between the macro-level (e.g. civilisation) ${ }^{38}$ and sub-cultures within different areas of law present within a given country. ${ }^{39}$ National legal culture is not static. Influences from outside (via imposition, legal transplant or membership of a regional organisation), as much as domestic political, economic and social dynamics transforms its content over time. For this reason, some voice doubt as to the continued existence of distinct national legal cultures in today's ever globalizing world. Nonetheless, differences among nations with respect to legal culture remain tangible. National traditions are known to be tenacious, as a result of which the storied common law-civil law distinction keeps its relevance despite claims to the contrary. Furthermore, the mechanism of local resistance to globalizing forces should not be underestimated. ${ }^{40}$

pour le droit international \& Deutsche Gesellschaft für Völkerrecht (eds), Les pratiques comparées du droit international en France et en Allemagne/Die Praxis des Völkerrechts im Vergleich zwischen Deutschland und Frankreich (2012).

${ }^{33}$ S L Bunn-Livingstone, Juriscultural Pluralism vis-à-vis Treaty Law (2002).

${ }^{34} \mathrm{~N}$ Kredel, Operation "Enduring Freedom" and the Fragmentation of International Legal Culture: Comparing US Common Law and Civil Law Perspectives on the International Use of Force (2006).

${ }^{35}$ E Menezes de Carvalho, Semiotics of International Law: Trade and Translation (2011).

${ }^{36}$ N L Arold, The Legal Culture of the European Court of Human Rights (2007); S McLaughlin Mitchell \& E J Powell, Domestic Law goes Global: Legal Traditions and International Courts (2011).

${ }^{37}$ Of course these are but some objects of diffusion at the international level. For a more expansive list, see: Twining, above n 13, 282. See also D Zartner Falstrom, 'Thought Versus Action: The Influence of Legal Tradition on French and American Approaches to International Law' (2006) 58 Maine LR 338, 343-7.

${ }^{38}$ See e.g. Y Ben Achour, Le rôle des civilisations dans le système international (droit et relations internationales) (2003); Y Onuma, A Transcivilizational Perspective on International Law (2010); H Köchler, 'Civilization and World Order: The Relevance of the Civilizational Paradigm in Contemporary International Law', in S Yee \& J Y Morin (eds), Multiculturalism and International Law: Essays in Honour of Edward McWhinney (2009) 65.

${ }^{39}$ M Van Hoecke \& M Warrington, 'Legal Cultures, Legal Paradigms and Legal Doctrine: Towards a New Model for Comparative Law' (1998) 47 ICLQ 495, 515.

${ }^{40}$ Nelken, above n 11, 120-3. 
In an attempt to avoid excessive ambiguity and abstraction, we will narrow our scope down to the internal legal culture of international law. The latter is inhabited by lawyers, jurists, judges, and similar actors (professionals) to be differentiated from the external legal culture, which deals with the aggregate perspectives of outsiders on the law (lay persons). ${ }^{41}$ One noteworthy effort to catalogue the basic elements comprising the internal world of legal culture led to the following set of characteristics shared by a given professional community: (1) a concept of law; (2) a theory of legal sources; (3) legal methodology; (4) a theory of acceptable argumentation; (5) a theory of legitimation; (6) a basic ideology. ${ }^{42}$ Other recurring elements include inter alia modes of reasoning and a distinct technical lexicon of terms, which at times differ semantically from ordinary language. ${ }^{43}$ Here it is important to note that one would be hard pressed to find a single international legal culture. There seems to be a growing consensus that the many branches of the legal system are giving rise to their own inner cultures shared by their respective professional communities. This holds particularly true for trade-related areas such as international commercial arbitration, ${ }^{44}$ investments, ${ }^{45}$ and law \& development, ${ }^{46}$ but it is equally valid for international criminal law. ${ }^{47}$

\subsubsection{Factors of influence: individual and structural}

Focus on practitioners, the individuals that breathe life into norms, is warranted for a number of reasons. The role they play in the development of international law is greater than that of their peers in national systems. ${ }^{48}$ Their writings are

${ }^{41}$ L M Friedman, The Legal System: A Social Science Perspective (1975) 194, 223. See also Cotterrell, above $\mathrm{n} 4,710$, who uses the term 'professional juristic realm'.

${ }^{42}$ Van Hoecke \& Warrington, above n 39, 514-15.

${ }^{43}$ G Rebuffa \& E Blankenburg, 'Culture juridique', in A J Arnaud et al (eds), Dictionnaire encyclopédique de théorie et de sociologie du droit (2 $2^{\text {nd }}$ edn, 1993) 139.

${ }^{44}$ E.g. Y Dezalay \& B G Garth, Dealing in Virtue: International Commercial Arbitration and the Construction of a Transnational Legal Order (1998).

${ }^{45}$ E.g. S W Schill, 'W(h)ither Fragmentation? On the Literature and Sociology of International Investment Law' (2011) 22 EJIL 875.

${ }^{46}$ E.g. C Picker, 'International Trade and Development Law: A Legal Cultural Critique' (2011) $4 \mathrm{~L}$ Es Develop R (2011) 42.

${ }^{47}$ E.g. M Bohlander, 'Radbruch Redux: The Need for Revisiting the Conversation between Common and Civil Law at Root Level at the Example of International Criminal Justice' (2011) 24 Leiden JIL 393.

${ }^{48}$ R Jennings, 'International Lawyers and the Progressive Development of International Law', in J Makarczyk (ed), Theory of International Law at the Threshold of the $21^{\text {st }}$ Century (1996) 413, 414; C G 
formally acknowledged as an aid in determining the rules of law. ${ }^{49}$ It is their opinion, operating as a collective, that makes or breaks the persuasiveness of a legal argument. ${ }^{50}$ Moreover, they have been subjected to a process of socialisation or enculturation in their respective societies, leading to the internalisation of certain values. ${ }^{51}$ They play a significant role in inducing rule compliance, ${ }^{52}$ and as norm carriers they export their traditions and values to the international level. ${ }^{53}$

Almost intuitively one surmises that two antagonistic forces are at play within the minds of these professionals. On the one hand, there is a powerful drive to assert distinctiveness. Now we have entered what is deemed by many to be the 'post-ontological' phase of international law, ${ }^{54}$ this coming of age goes hand in hand with the emergence of a legal culture in its own right. ${ }^{55}$ Schachter memorably encapsulated this sentiment when he spoke of the invisible college of international lawyers. ${ }^{56}$ This amorphous, cosmopolitan community of professionals is committed to the advancement of a common intellectual endeavor and boasts diverse membership from all corners of the globe. Its aim is to imbue legal concepts with a sense of justice (la conscience juridique). ${ }^{57}$

And still, this cannot be the complete picture. While highlighting the significance of the invisible college, Schachter equally acknowledged the pull of the national. Supporting a national outlook cannot simply be attributed to political gain or reasons of careerism. Rather, an individual is inculcated with values prevalent within his or her country, resulting in what he called 'inherent parochialism'. ${ }^{\text {, }}$ Some have highlighted the risks associated with such unconscious influences at

\footnotetext{
Weeramantry, Universalising International Law (2004) 76-83.

${ }^{49}$ Statute of the International Court of Justice, Art 38(1)(d) (ICJ Statute).

${ }^{50}$ M Koskeniemmi, 'Methodology of International Law', in R Wolfrum (ed), Max Planck Encyclopedia of Public International Law (online edn, 2008) MN1.

51 A D Renteln, 'Cultural Bias in International Law' (1998) 92 ASIL Proc 232, 233.

${ }^{52}$ E.g. L A Dickinson, 'Military Lawyers on the Battlefield: An Empirical Account of International Law Compliance’ (2010) 104 AJIL 1.

${ }^{53}$ K T Gaubatz \& M MacArthur, 'How International is "International” Law?' (2001) 22 Mich JIL 239, 264.

${ }^{54}$ See T M Franck, Fairness in International Law and Institutions (1998) 6.

${ }^{55}$ Renteln, above n 51, 236.

${ }^{56}$ O Schachter, 'The Invisible College of International Lawyers' (1977) 72 Northwestern U LR 217.

${ }^{57}$ Ibid, 225-6. The term derives from the Statutes of the Institute of International Law, Art 1.2.a. For a discussion on its origins and meaning, see: M Koskeniemmi, The Gentle Civilizer of Nations: The Rise and Fall of International Law 1870-1960 (2004) 41, 47-51.

${ }^{58}$ Schachter, above $\mathrm{n} 56,219$. For a debate on whether international lawyers can be ideologically neutral, see: A Cassese \& J H H Weiler (eds), Change and Stability in International Law-Making (1988) 137-63. See also G Guillaume, 'Some Thoughts on the Independence of International Judges vis-à-vis States’ (2003) 2 LPICT 163, 167-8.
} 
the international level which can 'hamper communication [...] and lead to misconceptions [...]. ${ }^{59}$

In addition to unconscious individual influences, structural aspects of the international legal order facilitate the filtering in of domestic legal patterns. The most conspicuous instance can be found in the general principles of law set out in Art 38.1.c of the ICJ Statute, a gateway for municipal concepts and institutions to trickle into the fabric of international law. Another factor is the ubiquitous 'equitable geographical representation' requirement which guides the UN's and other international organisations' hiring and election policies. ${ }^{60}$ With respect to the International Law Commission, the UN body whose mission it is to take on the codification and progressive development of international law, this condition is further specified in a manner that advances domestic juridical influences:

At the election the electors shall bear in mind that the persons to be elected to the Commission should individually possess the qualifications required and that in the Commission as a whole representation of the main forms of civilization and of the principal legal systems of the world should be assured. ${ }^{61}$

Besides the uncontroversial features, it is well worth asking whether there are conscious concerted efforts to promote national legal traditions in hammering out regimes, building international institutions etc. In other words, do states (and by extension their citizens in positions of relevance for the making and/or application of international law) ${ }^{62}$ enter into competition with one another to push through or even 'sell' their respective model? ${ }^{63}$ By way of illustration, after the political decision has been taken to establish a new international court or tribunal, the thrashing out of the legal details ensues. ${ }^{64}$ Certain writers have put forward the thesis that once they have entered that phase, states attempt to lock in their preferences in the design of the adjudicatory body. These preferences

\footnotetext{
${ }^{59}$ L Prott, The Latent Power of Culture and the International Judge (1979) 230.

${ }^{60}$ E.g. Charter of the United Nations, Art 101(3).

${ }^{61}$ Statute of the International Law Commission, Art 8. See also S Sucharitkul, 'Legal Multiculturalism and the International Law Commission', in Yee \& Morin, above n 38, 301.

${ }^{62} \mathrm{~F}$ Coulée, 'L'influence française sur le droit international', in Société française pour le droit international, above $\mathrm{n} 32,9,11-12$.

${ }^{63}$ E Jouannet, 'French and American Perspectives on International Law: Legal Cultures and International Law' (2006) 58 Maine LR 291, 300.

${ }^{64}$ D D Caron, 'Towards a Political Theory of International Courts and Tribunals' (2006) 24 Berkeley JIL 401, 409.
} 
include the absorption of features inspired by domestic legal traditions. ${ }^{65}$ This is particularly true in the case of the ICC and ad hoc criminal tribunals, which fuse elements of civil and common law procedure, thereby forming 'hybrid' entities. ${ }^{66}$

Others downplay this phenomenon. In 2001, the French Conseil d'État (the supreme administrative court) disseminated a study it had commissioned on the influence of French law in the world. The report concluded that 'juridical competition' is by and large absent in international law, as opposed to fields such as private international law and economic law where this dynamic is prevalent. ${ }^{67}$

\section{The ICJ as a microcosm of legal cultures}

The World Court, as a premier meeting place of international legal actors from variegated legal cultures, ${ }^{68}$ presents itself as a fitting institution for observing provincial idiosyncrasies. Drawing upon the (embryonic) theoretical thoughts set out in the above paragraphs, we will consider the individual and structural factors of influence and their resulting effect in the ICJ's case law.

\subsection{Judges}

Does the influence of national background linger in the recesses of many an international judge's mind? It seems hard to believe that adjudicators can leave their intellectual baggage at the doorstep upon entering the Peace Palace. A considerable number of judges have refuted or minimized the impact of domestic traditions on judicial behavior and ratiocination. A fortiori some of them have called into question the ability to reproduce their thought patterns. ${ }^{69}$ A stark illustration of this tendency is the following interview with former Judge Singh (India):

${ }^{65} \mathrm{~J}$ M Thouvenin, 'Cultures juridiques et procédures judiciaires', in Société française pour le droit international, above n 32, 387, 390.

${ }^{66}$ W W Burke-White, 'International Legal Pluralism' (2003) 25 Mich JIL 963, 974; G P Fletcher, 'The Influence of the Common Law and Civil Law Traditions on International Criminal Law', in A Cassese (ed), The Oxford Companion to International Criminal Justice (2009) 104.

${ }^{67}$ Conseil d'État - Section du rapport et des études, L'influence internationale du droit français (2001) $32-33$.

${ }^{68}$ See J G Merrills, International Dispute Settlement ( ${ }^{\text {th }}$ edn, 2011) 145 (noting that the ICJ does not have a single legal culture).

${ }^{69} \mathrm{M}$ Bedjaoui, 'Expediency in the Decisions of the International Court of Justice' (2000) 71 BYIL 1, $6-8$. 
Question: Fifteen countries are represented at the Court, some of them from radically different legal systems. Do you ever have difficulties in the value-orientation, the approaches of the judges, the fact that they come to the court with different national perspectives?

Answer: No. We all administer international law, which is the expertise of all these judges. We do not administer national laws, and I am glad to state international law is now a well established regional branch of law to govern inter-state relations.

Question: Has your coming from a country like India-with its great diversity, its population, its problems-helped you as a judge of the International Court?

Answer: Most certainly, because the world is full of diversity. It has different cultures, different languages, different religions, and in India you get in miniature what you see in the whole world. So it is an advantage for me to be well aware that these facts exist. They have to be reconciled and they have to be accepted. You cannot do anything to brush them aside. If you do, then you are working against reality. In any case, these differences are of no avail in the administration of international justice. They do not count. ${ }^{70}$

In other interviews, or even in separate opinions, ${ }^{71}$ fellow members of the bench have overwhelmingly asserted their freedom from parochial peculiarities. There is more than one explanation for this trend, however the most plausible reason is sending a clear signal of independence as well as impartiality. ${ }^{72}$ Without these indispensible qualities, the widely held assertion that initiating proceedings against another state is not an inimical act would be undermined. ${ }^{73}$

${ }^{70}$ G Sturgess \& P Chubb, Judging the World: Law and Politics in the World's Leading Courts (1988) 453; Renteln, above n 51, 242-3.

${ }^{71}$ Military and Paramilitary Activities in and against Nicaragua (Nicaragua v US), ICJ Reports $1986 \mathrm{p}$ 158, 158-60 (Judge Lachs, sep op).

72 On the independence/impartiality distinction, see: Institute of International Law, Resolution: The Position of the International Judge, 9 September 2011; J Malenovský, 'L'indépendance des juges internationaux' (2010) 349 RCADI 9, 29-30.

${ }^{73}$ See GA Res 3232(XXIX), 12 November 1974, op para 6: "[The UN General Assembly] [r]eaffirms that recourse to judicial settlement of legal disputes, particularly referral to the International Court of Justice, should not be considered an unfriendly act between States'(emphasis original); M Kdhir, 'La méthode de travail du juge international', in M Bedjaoui et al, La méthode de travail 
From an institutional perspective, this issue harks back to the perennial problem of the ICJ, the lack of compulsory jurisdiction. In order to convince states to submit their disputes to the Court, its members need to believably demonstrate they are unbiased. Accusations of this ilk were especially widespread in the aftermath of the symbolic case Nicaragua $v$ US. ${ }^{74}$ In past years, scholars have added to this slew of writings, providing more refined studies for detecting biases among the World Court's judges. ${ }^{75}$ Despite these understandable concerns, the odd admission of domestic influence has surfaced. The most candid instance to our mind is a dissenting opinion written by an ad hoc judge in the Anglo-Iranian Oil Co case:

It is inevitable that everyone of us in this Court should retain some trace of his legal education and his former legal activities in his country of origin. This is inevitable, and even justified, because in its composition the Court is to be representative of 'the main forms of civilization and of the principal legal systems of the world'(Statute, Article 9), and the Court is to apply 'the general principles of law recognized by civilized nations'. (Statute, Article 38(1)(c)). ${ }^{76}$

In addition, some who have served at the ICJ have cautiously acknowledged that certain legal concepts emblematic of a given legal tradition can prove quite divisive among their peers. Judge Jennings, a former President of the Court from the UK, noted:

The only time, in the writer's experience, when a difference of legal culture seems to appear is when a counsel trained in the common

du juge international (1997) 9, 31. See also N Singh, The Role and Record of the International Court of Justice (1989) 30 (reporting the general perception that states sometimes drag their adversaries before the Court as part of a political ploy to get them to negotiate).

${ }^{74}$ E.g. E Gordon, 'Observations on the Independence and Impartiality of the Members of the International Court of Justice' (1987) 2 Connecticut JIL 397. This was, however, not the first time that members of the Court were accused of anti-Western bias (see E McWhinney, The International Court of Justice and the Western Tradition of International Law (1987) 137-139) nor the last (see G I Hernández, 'Impartiality and Bias at the International Court of Justice' (2012) 1 CJICL 183, 203-204 (on Judge Elaraby and the 2004 Israeli Wall Advisory Opinion)).

75 E.g. E Posner \& M de Figueiredo, 'Is the International Court of Justice Biased?' (2005) $34 \mathrm{~J}$ Leg Stud 599; A M Smith, “Judicial Nationalism” in International Law: National Identity and Judicial Autonomy at the ICJ' (2005) 40 Texas ILJ 197; E Voeten, 'The Politics of International Judicial Appointments' (2009) 9 Chicago JIL 387.

${ }^{76}$ Anglo-Iranian Oil Co (UK v Iran), ICJ Reports 1952 p 151, 161 (Judge Levi Carneiro, diss). 
law begins to cross-examine a witness; a procedure which one's colleagues from a different legal tradition often find odd and even embarrassing. ${ }^{77}$

Judge Guillaume, a French former ICJ President, recently observed that 'whenever the Court discusses estoppel or the word is uttered, all judges turn to their British colleague. ${ }^{78}$

A cursory overview of judges' attitudes teaches us that, yet again, the above-mentioned tension between the global (the need to claim universality for the sake of safeguarding the position of the ICJ) and the parochial (the inevitability of national legal culture playing a role whatever its significance) is ever-present in the thought processes of those sitting on the World Court's bench.

\subsection{Litigators}

To grasp the legal reasoning of a court in its entirety, one is well-advised to equally study counsel acting on behalf of the parties. ${ }^{79}$ Their impact on the outcome of the case is not to be neglected. ${ }^{80}$ Creative and convincing arguments could bring the Court to render a pioneering decision. In doing so, lawyers can implicitly contribute to the international law-making process. ${ }^{81}$ This international bar has been pithily described by one of their American doyens as consisting of:

\footnotetext{
${ }^{77}$ R Y Jennings, 'An International Lawyer Takes Stock' (1991) 1 U Miami YIL 1, 14-15. See also S Rosenne, The World Court: What it is and How it Works (1995) 131: '[A] general practice resembling the Anglo-American procedure is emerging, with its three phases of examination-in-chief, cross-examination and re-examination, although the rules of evidence in international procedure are less strict and formalistic than in common-law countries'.

${ }^{78}$ G Guillaume, 'Discutant' (2011) 115 RGDIP 417, 420 (own translation).

${ }^{79} \mathrm{O}$ Spiermann, International Legal Argument in the Permanent Court of International Justice (2005) 129; C B Picker, 'International Law's Mixed Heritage: A Common/Civil Law Jurisdiction' (2008) 41 Vanderbilt J Transnat L 1083, 1116 (n 184); C P R Romano, 'The Americanization of International Litigation' (2003) 19 Ohio State J Dispute Res 89, 91-2; K Highet, 'Book Review [of T D Gill, Litigation Strategy at the International Court: A Case Study of the Nicaragua $v$ United States Dispute (1989)]' (1992) 86 AJIL 400, 400: 'For a full understanding of practically any case one must go further, and read at least the key passages of the written pleadings and the high points of the oral arguments in the case. As with the proverbial iceberg: seven-eighths of the content of a case can be understood only if one dives beneath the frigid waters of the decision and tries to view the underlying shape of the litigation as a whole.'

${ }^{80}$ T D Gill, Litigation Strategy at the International Court: A Case Study of the Nicaragua v United States Dispute (1989) 328-337 (analysing the effects of strategy and tactics on the outcome of Nicaragua $v U S)$.

${ }^{81}$ A Boyle \& C Chinkin, The Making of International Law (2007) 291.
} 
[T] hose international lawyers who have practiced and who continue to practice as oral advocates before the Court, who represent a variety of foreign states other than their own governments, who are well-known to the Judges and Registrar of the Court, who know how things work out in practice, and who understand by experience the difficulties, pitfalls and tricks of the trade. ${ }^{82}$

As regards this professional elite, the juridical competition thesis (see above) might have currency. Gaubatz \& MacArthur have studied the composition of ICJ litigation teams in an effort to understand the dissemination of knowledge of international norms around the globe. Having crunched the numbers, their article concludes that the strong reliance of non-OECD states on Western lawyers ${ }^{83}$ for representation before the World Court is indicative of limited legal knowledge diffusion and local capacity. ${ }^{84}$

But even within the Western tradition, opinions diverge as to which legal cultures holds more sway. Looking back at a number of their oral and written submissions, as well as those of their predecessors, veteran ICJ lawyers Crawford $\&$ Pellet have concluded that traces of common law and civil law can be found in pleading practices. ${ }^{85}$ To this they add that, while differences exist, they are not insurmountable and generally are fairly nuanced. ${ }^{86}$ The relative weight to be attributed to oral and written submissions in persuading the Hague Court can arguably be seen as a clash between quintessential Anglo-Saxon and continental

${ }^{82}$ K Highet, 'A Personal Memoir of Eduardo Jiménez de Aréchaga: Doyen of the Invisible Bar of the International Court' (1994) 88 ASIL Proc 577, 578-579.

${ }^{83}$ See Rosenne, above n 77, 119-20 (noting that ICJ counsel and advocates are often seasoned members of their respective national bars and tend to come from a small group of countries, namely Belgium, UK, France, Italy, Switzerland and the US); A Pellet, 'The Role of the International Lawyer in International Litigation', in C Wickremasinghe (ed), The International Lawyer as Practitioner (2000) 147, 149.

${ }^{84}$ Gaubatz \& MacArthur, above n 53, 253.

${ }^{85}$ See also Gill, above $\mathrm{n} 80,48$ (claiming that World Court litigators do not share a common legal culture in contradistinction to their domestic counterparts).

${ }^{86} \mathrm{~J}$ Crawford \& A Pellet, 'Anglo Saxon and Continental Approaches to Pleading Before the ICJ / Aspects des modes continentaux et anglo-saxons de plaidoiries devant la CIJ', in I Buffard, J Crawford, A Pellet \& S Wittich (eds), International Law between Universalism and Fragmentation-Festschrift in Honour of Gerhard Hafner (2008) 831, 867. Combining both traditions can have clear advantages in pleadings, see: A Pellet, "The Anatomy of Courts and Tribunals' (2008) 7 LPICT 275, 278: 'I believe that the opportunity to address the International Court of Justice in both a language that constitutes a natural vehicle for common law and on the other hand one that is more linked to the particulars of Roman law is a source of complementary and mutual enrichment'. 
characteristics respectively. Some argue that the written aspect of litigation is 'predominant, ${ }^{87}$ whereas others hold that the written submissions are in fact 'subordinate to the oral proceedings' 88

Finally, Romano has detected potential patterns of Americanization in ICJ litigation. He attributes the developing trend of adversarial legalism, in particular mega-litigation (e.g. the sheer volume of pleadings in Gabčkovo-Nagymaros Project (Hungary/Slovakia)), and tactics of attrition (e.g. the prolific requests for provisional measures and formulations of counter-claims in Application of the Convention on the Prevention and Punishment of the Crime of Genocide (Bosnia and Herzegovina $v$ Serbia and Montenegro)) in part to the pressures of US influence. ${ }^{89}$

\subsection{Structure}

There are (at least) three key design features that militate in favor of domestic cultural influences within the Court. With respect to the selection of judges, we should call attention to the requirement that 'at every election, the electors shall bear in mind [...] that in the body as a whole the representation of the main forms of civilisation and of the principal legal systems of the world should be assured'. ${ }^{90}$

Indeed, when it comes to the selection of international judges, states are keen on recognizing the existence and importance of cultural diversity. ${ }^{91}$ Read in conjunction with Art 38 of the ICJ Statute, which acknowledges general principles as a formal source of law, this provision can be viewed as an encouragement to draw upon municipal legal traditions in fashioning international jurisprudence. In all fairness, this antiquated interpretation of the term 'principal legal systems of the world' has taken a backseat in light of the tremendous rise in volume and scope of customary norms, conventions and case law since the framing of the aforementioned rule. ${ }^{92}$

\footnotetext{
${ }^{87}$ Gill, above $n$ 80, 89-91 (asserting that written proceedings, as is the case in civil law jurisdictions, play a significant role, whilst according considerable importance to oral pleadings in requests for provisional measures).

${ }^{88}$ Highet, above n 79, 402; Rosenne, above n 77, 129.

${ }^{89}$ Romano, above n 79, 96-103.

${ }^{90}$ ICJ Statute, Art 9.

${ }^{91} \mathrm{G}$ de Lacharrière, 'Le point de vue du juriste: la production et l'application du droit international dans un monde multiculturel', in R J Dupuy (ed), L'avenir du droit international dans un monde multiculturel/The Future of International Law in a Multicultural World (1983) 67, 74.

92 B Fassbender, 'Article 9', in A Zimmermann, C Tomuschat \& K Oellers-Frahm (eds), The Statute of the International Court of Justice: A Commentary (2006) 261, 275.
} 
The blueprint of the ICJ can be viewed as encapsulating domestic legal traits. $^{93}$ In their recent book, McLaughlin Mitchell \& Powell have developed a rational legal design theory for explaining the linkage between a state's legal traditions and its behaviour towards creating ('the originators') and adhering to ('the joiners') international courts and tribunals. Central in this approach is the contention that states are eager to lock in their preferences, in the form of beneficial rules and procedures, so as to enhance the predictability of adjudicators' behaviour. National legal traditions can serve as indispensable clues for making such predictions, hence the incentive to mimic domestic adjudicatory aspects. ${ }^{94}$

A cautionary note is in order. Viewing a court's anatomy in legal cultural terms certainly produces interesting results. At the same time, it would be counter-factual to attribute every aspect of the ICJ's blueprint to domestic influences. Realpolitik can trump tradition. A marked case in point is the decision not to establish a system of stare decisis. It would seem logical to assume that the absence of binding precedent derives from the preponderant sway of the civil law experts entrusted with the task of setting up the Permanent Court of International Justice (PCIJ) (the Advisory Committee of Jurists), which in turn laid the groundwork for the ICJ. Yet the travaux préparatoires tell another story: the drafters were above all fearful of endowing international judges with the power to make law. It is equally telling in this regard that the British experts of the Committee agreed on this matter. ${ }^{95}$

\subsection{Case law}

Having determined the factors of influence within the ICJ, the next step consists in demonstrating how these variables manifest themselves in the outcome of the World Court's judicial process. Textual analysis of the rulings of the Court and concomitant inferences can only paint a partial picture of how the domestic

\footnotetext{
${ }^{93} \mathrm{H}$ Ascencio, 'La notion de juridiction internationale en question', in Société française de droit international (ed), La juridictionnalisation du droit international (2003) 163, 166 (asserting that international jurisdictional bodies are transposed from domestic law albeit with adaptations to fit their new social setting, i.e. the international community).

${ }^{94}$ McLaughlin Mitchell \& Powell, above n 36, ch 3. See also L Lloyd, "A Springboard for the Future": A Historical Examination of Britain's Role in Shaping the Optional Clause of the Permanent Court of International Justice' (1985) 79 AJIL 28, 37 (detailing the UK's successful efforts to prevent the PCIJ from having compulsory jurisdiction out of fear that a continental dominated bench would be pernicious to its interests).

${ }^{95}$ G Guillaume, 'The Use of Precedent by International Judges and Arbitrators' (2011) 2 JIDS 5, 8.
} 
element seeps into decision-making. We are insufficiently knowledgeable of the laborious internal process (redrafting, confidential meetings, the role of the secretariat's staff, etc.) that churns out the case law with which internationalists are so familiar. The literature on this topic is quite scarce. ${ }^{96}$

Not that this has prevented several publicists from reading legal culture into the jurisprudence of the Court. Areas in which the municipal effect is felt are inter alia the judge's perception of his or her social responsibilities (in particular, re-making positive law in response to changes in the international community as opposed to doing individual justice inter partes), ${ }^{97}$ the style of writing, ${ }^{98}$ the implementation of the adversarial principle, ${ }^{99}$ and the judicial activism/restraint dichotomy. ${ }^{100}$ There are two specific issues with regard to which the culture factor is substantial: resorting to analogy and the justification of decisions.

\subsubsection{Analogies}

Analogical reasoning is met with a fair amount of reluctance in classical doctrine if used to make a legal argument, because this could entail extending the application of a rule to a new situation without the consent of states to be bound. ${ }^{101}$ Despite theoretical trepidation, a great number of ICJ judges have found wisdom in analogies to domestic legal cultures. ${ }^{102}$ Such references can be

${ }^{96}$ R Y Jennings, 'The Internal Judicial Practice of the International Court of Justice' (1988) 59 BYIL 31, 36-47; M Bedjaoui, 'La "fabrication” des arrêts de la Cour internationale de Justice', in Le droit international au service de la paix, de la justice et du développement: Mélanges Michel Virally (1991) 87.

${ }^{97}$ E McWhinney, Judicial Settlement of International Disputes (1991) 19-20.

${ }^{98} \mathrm{G}$ Guillaume, 'Cultures juridiques et délibéré judiciaire', in Société francaise pour le droit international, above n 32, 399; J A R Nafziger, 'Some Remarks on the Writing Style of the International Court of Justice', in T Buergenthal (ed), Contemporary Issues in International Law: Essays in Honour of L B Sohn (1984) 325; L Prott, "The Style of Judgment in the International Court of Justice' (1970) 5 Australian YIL 75.

${ }^{99}$ E Jouannet, 'Remarques conclusives', in H Ruiz Fabri \& J M Sorel (eds), Le principe du contradictoire devant les juridictions internationales (2004) 177, 188-94.

${ }^{100} \mathrm{E}$ McWhinney, 'The International Court of Justice and International Law-making: The Judicial Activism/Self-Restraint Antinomy' (2006) 5 Chinese JIL 3; E Jouannet, 'Remarques conclusives', in H Ruiz Fabri \& J M Sorel, Indépendance et impartialité des juges internationaux (2010) 271, 298-9. See also Koch, above n 21, 42-3 (arguing that deciding a non liquet could be viewed as reflecting constraint for lack of a sound legal source, which in turn is telling of the civil law tradition).

${ }^{101}$ S Vöneky, 'Analogy in International Law', in R Wolfrum (ed), Max Planck Encyclopedia of Public International Law (online edn, 2008) MN18-22.

${ }^{102}$ But cf Reparation for Injuries Suffered in the Service of the United Nations, ICJ Reports 1949 p 205, 211 (Judge Badawi Pacha, diss). 
categorized into two types: ${ }^{103}$ resort to private law ${ }^{104}$ and comparative law. ${ }^{105}$ While it is understandable that analogies allow a practitioner to 'feel more at home, ${ }^{106}$ the outcome of excessive usage is not always benign. The danger lies in importing one's preferred legal concepts wholesale into international law under the guise of general principles. ${ }^{107}$ As stated by a former Soviet Judge on the Court, Korovin: '[l]ong ago there were warnings against the danger of an unreserved transference of the principles of civil law and process into international (public) law and into the procedure of international courts'.108

Judge Weeramantry appealed to the readers of his separate opinion to 'draw upon the world's diversity of cultures' in the making of international legal norms. $^{109}$

This phenomenon is not as pervasive as it used to be. Especially in the time of the PCIJ, frequent recourse to domestic juridical concepts was necessary in constructing the building blocks of international law. ${ }^{110}$ As international law

\footnotetext{
${ }^{103}$ Prott, above n 59, 212-16; Butler, above n 18, 39-41.

${ }^{104}$ E.g. South West Africa (Ethiopia v South Africa; Liberia v South Africa), ICJ Reports 1966 p 325, 386-8 (Judge Jessup, diss) (South West Africa) (on standing to secure judicial review); Barcelona Traction, Light and Power Company, Limited (Belgium v Spain) (New Application: 1962), ICJ Reports 1970 p 114, 117-18 (Judge Tanaka, sep op) (Barcelona Traction) (on the characteristics of corporations).

${ }^{105}$ E.g. Northern Cameroons (Cameroon v United Kingdom), ICJ Reports 1963, p 150 (Judge Badawi, diss) (a comparative overview of declaratory judgments); Judgments of the Administrative Tribunal of the ILO upon Complaints made against Unesco, ICJ Reports 1956 p 123, 132-4 (Vice-President Badawi, diss) (a comparative overview of détournement de pouvoir doctrine in several legal systems); Barcelona Traction, ICJ Reports 1970 p 267, 273, 285 (Judge Gros, sep op) (citing examples of bankruptcy legislation).

${ }^{106} \mathrm{H}$ Thirlway, 'Concepts, Principles, Rules and Analogies: International and Municipal Legal Reasoning' (2002) 294 RCADI 265, 405. Even when an international and a municipal legal notion are quite different, analogy can allow for a better delineation between the two, thereby sharpening conceptual understanding, see: M Shahabuddeen, 'Municipal Law Reasoning in International Law', in A V Lowe \& M Fitzmaurice (eds), Fifty Years of the International Court of Justice: Essays in Honour of Sir Robert Jennings (1996) 90, 99-102.

${ }^{107} \mathrm{H}$ Lauterpacht, Private Law Sources and Analogies of International Law (with Special Reference to International Arbitration) (1927) 84-5; L B Wehle, 'Comparative Law's Proper Task for the International Court' (1950) 99 U Penn LR 13, 19 (explaining that prior to the PCIJ, international law mainly drew upon Roman-Civil concepts); J Ellis, 'General Principles and Comparative Law' (2011) 22 EJIL 949, 955ff.

${ }^{108}$ South West Africa (Ethiopia v South Africa; Liberia v South Africa), ICJ Reports 1966 p 239, 242 (Judge Koretsky, diss).

${ }^{109}$ Gabčkovo-Nagymaros Project (Hungary/Slovakia), ICJ Reports 1997 p 88, 96 (Vice-President Weeramantry, sep op).

${ }^{110}$ L Ferrari-Bravo, 'International and Municipal Law: The Complementarity of Legal Systems', in R St J Macdonald \& D M Johnston (eds), The Structure and Process of International Law: Essays in
} 
grew exponentially in quality and quantity, the need to seek refuge in analogies grew less acute.

\subsubsection{Justificatory practices}

Giving reasons is an intrinsic quality of judicial decisions. ${ }^{111}$ This is not only of concern to the parties, but the wider audience that the Court has to convince. ${ }^{112}$ Depending on the issues at stake and the potential political/economic impact of the outcome, reasons are important for persuading the citizens of the litigating states as well as other countries and their peoples. ${ }^{113}$ How a judge goes about justifying his or her verdict is intimately connected to legal culture. Within the ICJ, the common law and civil law approaches to judicial motivation are in some instances at odds. The clash is exacerbated by the relative vacuum in which the bench must operate: Art 56 of the Statute provides that ' $t$ ]he judgment shall state the reasons on which it is based' and Art 95.1 of the Rules of the Court stipulate that 'the judgment [...] shall contain [...] the reasons in point of law' without elaborating further on this important issue. ${ }^{114}$

The meeting of the legal cultures clearly comes to the fore with respect to the format of legal reasoning. In the Anglo-Saxon tradition, the adjudicator is more amenable to adapting the ruling to the social context (legitimacy) and aims to win over the parties and the public at large (pedagogical), resulting in decisions that answer to the parties' contentions and that adopt a style known to be somewhat prolix and conversational. ${ }^{115}$ Continental judges however are more intent on applying written codes, work on the basis of deductive syllogisms and aim to express what they deem is the 'legal truth' without feeling obligated to address all proffered arguments. ${ }^{116}$ How does this play out at the ICJ? Vasseur notes that

\footnotetext{
Legal Philosophy, Doctrine and Theory (1983) 715, 724.

${ }^{111}$ P M Juret, 'Observations sur la motivation des décisions juridictionnelles internationales' (1960) 64 RGDIP 516, 519; R Y Jennings, 'Judicial Reasoning at an International Court', in G Ress (ed), Vorträge, Reden und Berichte aus dem Europa-Institut (1991) 1, 2.

${ }^{112}$ G Cahin, 'La motivation des décisions de la Cour internationale de justice', in H Ruiz Fabri \& J M Sorel, La motivation des décisions des juridictions internationales (2008) 9, 81.

${ }^{113}$ G A Alvarez \& W M Reisman (eds), The Reasons Requirement in International Investment Arbitration (2008) 2; L Prott, 'The Justification of Decisions in the International Court of Justice', in C Perelman \& P Foriers (eds), La motivation des decisions de justice (1978) 331, 333-4.

${ }^{114}$ See also Interpretation of the Agreement of 25 March 1951 between the WHO and Egypt, ICJ Reports 1980 p 125, 125 (Judge Mosler, sep op).

${ }^{115}$ A Vasseur, 'L'influence des traditions juridiques nationales sur la motivation des décisions de la Cour internationale de justice' (2007) 40 RBDI 474, 485.

${ }^{116}$ Ibid, 485-6.
} 
in a first period the bench was willing to answer the litigating states' arguments in detail, including the underlying rationale behind them, however a shift occurred with the Court becoming less inclined to engage with the parties' submissions. ${ }^{117}$

Can this seeming rapprochement to civil legal thought be counted as a win for continental-style international lawyers? Not quite. While national legal culture certainly explains this occurrence in part, there are other factors that have brought about this result. One explanation is that the Court writes a majority opinion, trying to get as many judges on board. Consensus-building automatically leads to a watered down and more laconic decision. ${ }^{118}$ Following a strategic logic, it could also be argued that the ICJ, lacking compulsory jurisdiction, does not want to openly and in a detailed fashion tear apart a state's arguments for fear of scaring away potential parties, and thus limits itself to the bare essentials. ${ }^{119}$

\subsubsection{Standard of proof}

Due to patently capacious rules in its Statute and Rules, the Court enjoys a great deal of leeway in assessing evidentiary materials. ${ }^{120}$ Precisely because of this juridical vacuum, the members of the bench have felt compelled to hammer out their own approach to dealing with facts in individual cases without much textual guidance. ${ }^{121}$ An area where this has induced a culture clash of sorts is the standard of proof, i.e. the degree to which a claimant must demonstrate to a tribunal's satisfaction that the assertion holds true. ${ }^{122}$ This predicament was intelligibly framed by former President Higgins in an address to the Sixth Committee of the UN General Assembly:

[T]he Court has [...] been reluctant to specify the standard of proof, even for a particular case. [...] Part of this reluctance to be specific is caused by the gap between the explicit standard-setting approach

\footnotetext{
${ }^{117}$ Ibid, 488. See also H Thirlway, 'The Drafting of ICJ Decisions: Some Personal Recollections and Observations' (2006) 5 Chinese JIL 15, 26-27.

${ }^{118}$ Guillaume, above n 98, 401. See also Cahin, above n 112, 20.

${ }^{119}$ Vasseur, above n 115, 489. Cf Cahin, above n 112, 53-6.

${ }^{120} \mathrm{C}$ Brown, A Common Law of International Adjudication (2009) 87. This discretion extends to both admission and assessment of evidence. See G Niyungeko, La preuve devant les juridictions internationales (2005) 239ff, $322 \mathrm{ff}$.

${ }^{121}$ M Benzing, Das Beweisrecht vor internationalen Gerichten und Schiedsgerichten in zwischenstaatlichen Streitigkeiten (2010) $512 \mathrm{ff}$.

${ }^{122}$ C F Amerasinghe, Evidence in International Litigation (2005) 232.
} 
of the common law and the "intime conviction du juge" familiar under civil law; the ICJ naturally has judges from both of these traditions on its Bench. ${ }^{123}$

As a result of this impasse, a fair number of judges, often of common law heritage, have handed down individual, separate or dissenting opinions in which they lament the majority's inability to establish a sound methodology ${ }^{124}$ and/or set the standard they believe should apply in the contentious case before them. ${ }^{125}$ Here cultural sway, despite its acknowledged relevance in the field of evidence law, ${ }^{126}$ should be somewhat nuanced. Firstly, the background of judges is not the only factor of influence determining to what degree facts must be established. Other indicators are the nature of the dispute at hand (e.g. sorting out competing maritime/territorial claims as opposed to findings of state responsibility for internationally wrongful acts), the seriousness of the allegations and the phase of proceedings (e.g. merits or incidental). ${ }^{127}$ Secondly, it has been pointed out that a judge will not always be inclined to follow the evidentiary approach of his or her country of origin. ${ }^{128}$

\footnotetext{
${ }^{123} \mathrm{H}$ E Judge Rosalyn Higgins, President of the International Court of Justice, 'Speech to the Sixth Committee of the General Assembly', 2 November 2007, 4-5, <http://www.icj-cij.org/presscom/files/3/14123.pdf> [accessed 1 May 2013]. Cf Dispute concerning Delimitation of the Maritime Boundary between Bangladesh and Myanmar in the Bay of Bengal (Bangladesh/Myanmar), Judgment of 14 March 2012, 9 (Judge Lucky, diss): 'It would appear from its case law that the ICJ adopts the civil law method'.

${ }^{124}$ Oil Platforms (Iran v US), ICJ Reports 2003 p 225, 233-5 (Judge Higgins, sep op).

${ }^{125}$ Pulp Mills on the River Uruguay (Argentina v Uruguay), ICJ Reports 2010 p 14, 230 (Judge Greenwood, sep op).

${ }^{126} \mathrm{~B}$ Simma, 'The International Court of Justice and Scientific Expertise-Fact-Finding in Interstate Disputes' (2012) 106 ASIL Proc 230, 230 (referring to a 'clash of (legal) civilizations'); C Greenwood, 'Some Challenges of International Litigation' (2012) 1 CJICL 7, 17-18 (stating the limited relevance of legal tradition save procedural matters such as evidence).

${ }^{127} \mathrm{~K}$ Del Mar, 'The International Court of Justice and Standards of Proof', in K Bannelier, T Christakis \& S Heathcote (eds), The ICJ and the Evolution of International Law: The Enduring Impact of the "Corfu Channel" Case (2012) 98.

${ }^{128}$ A Riddell \& B Plant, Evidence before the International Court of Justice (2009) 37. See Kasikili/Sedudu Island (Botswana/Namibia), ICJ Reports 1999 p 1045, 1233 (Judge Rezek, diss) (a Brazilian judge referring to 'preponderance of evidence', a standard of proof that is not part of civil law systems of evidence).
} 


\section{Conclusion}

The aim of this paper has been to open up a discussion on the merits and pitfalls of adopting a legal cultural approach to international law. Possibilities abound and many methodological aspects are still untapped. By way of illustration, an in-depth comparative study of the teaching of international law ${ }^{129}$ would offer fascinating insights, legal training being paramount in the shaping of professional culture. ${ }^{130}$ Such a venture would moreover raise a host of questions on how to go about it. One could certainly imagine that scrutinizing educational practices would involve comparative textbook analysis ${ }^{131}$ and a closer look at the manner in which international law courses are integrated into the wider curriculum. ${ }^{132}$

Other than these methodological queries, there are deeper issues worthy of consideration. To what extent does the absorption of municipal elements in the global legal order enhance political acceptability and compliance pull of the system? ${ }^{133}$ Why should we study international law in comparative perspective and what are we aiming to demonstrate? ${ }^{134}$ Even if we acknowledge the existence of municipal influences on judges in their decision-making, have they created an institutional legal culture of their own that transcends the parochial and what can be said of its constitutive elements? ${ }^{135}$ In any event, novel scholarship in this field will enable us to move from the educated hunch that national legal culture

\footnotetext{
${ }^{129}$ Koskenniemi, above n 30, 3.

${ }^{130}$ Based on the findings, suggestions could be made to counter insularity in international legal education. See J A Cohen, 'Ethnocentrism and the Teaching of International Law', in R St J Macdonald (ed), Essays in Honour of Wang Tieya (1994) 191.

${ }^{131}$ L Mälksoo, 'International Law in Russian Textbooks: What's in the Doctrinal Pluralism?' (2009) 1 Goettingen JIL 279; A Toublanc, 'Concerning French International Law Manuels: A Critical Review of the Principal French Textbooks in Public International Law' (2006) 58 Maine LR 587.

${ }^{132}$ See E D Brown, 'The Teaching of International Law in the United Kingdom', in B Cheng (ed), International Law: Teaching and Practice (1982) 167; J Dutheil de la Rochère, "The Teaching of Public International Law in France', in ibid, 183; J Klabbers \& M Sellers (eds), The Internationalization of Law and Legal Education (2008). See also: International Law Association (ILA), Teaching of International Law Committee (1998-2010).

${ }^{133}$ Cf Burke-White, above n 66, 978-9 with Spiermann, above n 79, 404.

${ }^{134}$ Cf Mamlyuk \& Mattei, above n 18, 393-4 (embracing difference, understanding but not transforming extant approaches to international law, matching coterminous projects in international and comparative legal studies) with Picker, above n 79, 1086-9 (improving international rules and institutions based on lessons from comparative law).

${ }^{135}$ D Terris, C P R Romano \& L Swigart, The International Judge: An Introduction to the Men and Women Who Decide the World's Cases (2007) 65 (referring to this institutional culture as the united approach to justice'); M Lachs, 'A Few Thoughts on the Independence of Judges of the International Court of Justice' (1987) 25 Columbia JTL 593, 595.
} 
matters in international law to thoroughly substantiated claims. 